\title{
Epiphytic metazoans on emergent macrophytes in oxbow lakes of the Krapina River, Croatia: differences related to plant species and limnological conditions
}

\author{
Maria Šroljar ${ }^{* 1}$, Jelena Fressl $^{2}$, TVRTKo DražInA ${ }^{1}$, MatiJa Meseljević ${ }^{3}$, \\ ZLATKO GRČIĆ ${ }^{4}$ \\ ${ }^{1}$ Department of Zoology, Division of Biology, Faculty of Science, University of \\ Zagreb Rooseveltov trg 6, HR-10000 Zagreb, Croatia \\ ${ }^{2}$ Dvokut Ecro Ltd., Environmental Protection and Sustainable Development, \\ Trnjanska 37, HR-10000 Zagreb, Croatia \\ 3 ANT Ltd., Lab for analyses and toxicology, Medarska 69, HR-10 090 \\ Susedgrad-Zagreb, Croatia \\ ${ }^{4}$ Sanatio Ltd, Bolnička cesta 34c, HR-10 090 Susedgrad-Zagreb, Croatia
}

\begin{abstract}
This study investigated the structure of the epiphytic metazoans on emerged macrophytes in the littoral zone of two oxbow lakes with different trophic levels. Differences in the diversity and density of the epiphytic metazoans were analyzed in relation to plant architecture (simple or complex stems), food resources (algae and detritus) and water characteristics (transparency and derived trophic state index). A significant negative correlation was found between detritus on plants as food resource, and diversity and density of epiphytic metazoans, indicating grazing of microphagous species. Rotifers dominated in diversity and density in the epiphyton on all habitats. Total density of metazoans, rotifers and copepods in epiphyton were significantly higher on Mentha in mesotrophic lake than on Iris in a eutrophic lake. We presume that macrophyte belt width and trophic state governed biotic interactions and consequently epiphytic assemblages more strongly than macrophyte architecture. However, a Mentha habitat showed a slightly higher density and diversity of epiphytic metazoans in relation to Iris at the same site, but these differences were not significant.
\end{abstract}

Key words: Macrophyte, Mentha, Iris, epiphyte, metazoans, trophic state, trasnparency, biotic interactions

\section{Introduction}

Shallow lakes are unique fresh water ecosystems, long overlooked in limnological research, despite their great biodiversity of algae, macrophytes, plankton, nekton and benthos

\footnotetext{
* Corresponding author, e-mail: mspoljar@zg.biol.pmf.hr

Copyright $^{\circledR} 2012$ by Acta Botanica Croatica, the Faculty of Science, University of Zagreb. All rights reserved.
} 
(CASTRO et al. 2005). Many of these shallow lakes are endangered by eutrophication, acidification and introduction of invasive species (KALFF 2002). Anthropogenic eutrophication is one of the main triggers in shifting shallow lakes from a clear-water macrophyte-dominated state to a turbid-water phytoplankton-dominated state (SCHEFFER et al. 1993, KÖHLER et al. 2005, HILT et al. 2010). Macrophytes often characterize littoral zones of shallow lakes and have an important role in water biocenoses, structuring and modifying the physical-chemical features by photosynthesis, decomposition and mineralization (DUGGAN et al. 2001, JEPPESEN et al. 2002, JONIAK et al. 2007). They reduce water movement and sediment resuspension, provide refuge and protection to zooplankton, macroinvertebrates and small fish against predators (CHAMBERS et al. 2008) and serve as oviposition habitats for fish, water birds and invertebrates (WALSH 1989, BECCERA-MunOZ and SCHRAMm 2007, KLASSEN and NOLET 2007). So far, studies on the role of macrophytes in littoral habitats have mostly been focused on submerged (HORPPILA and NURMINEN 2001, KUCZYŃSKA-KIPPEN and KLIMASZYK 2007, SøNdERGAARD et al. 2007, Bogut et al. 2010, Hilt et al. 2010) and less on emerged macrophytes (CAZZANELLi et al. 2008, ŠPOLJAR et al. 2011). This can be explained by reference to several circumstances. The greater surface area of well dissected submerged macrophytes may benefit invertebrates by offering better food resources and protection against predators than macrophytes with simple stems (MEERHOFF et al. 2007, TESSIER et al. 2008). Moreover, complex macrophytes respond promptly to eutrophication effects and are obligate in lake restoration (Moss et al. 1997, HILT et al. 2006).

The epiphyton community has an important role in the primary production of shallow lakes (CATTANEO et al. 1998, LAguste and REunANEN 2005). Epiphyton is composed of detritus, bacteria, algae, fungi, protozoan and metazoan invertebrates attached to aquatic macrophytes (WETZEL 2001). It is a result of several factors and has a keystone position in the food web and nutrient circulation since it is sensitive to both bottom-up and top-down control mechanisms (JEPPESEN et al. 1999). Macrophyte architecture (simple or complex stem with dissected leaves) and surface structure are important factors in epiphyton development (VIEIRA et al. 2007, TESSIER et al. 2008). Macrophytes with dissected leaves and more structural complexity provide a suitable area for epiphyton growth characterised by higher biodiversity than those with undissected leaves (LAGUSTE and REUNANEN 2005). Light together with nutrients (phosphate, nitrate) are the main abiotic limiting factors, and they affect growth, development, density and diversity of aquatic macrophytes and epiphyton (CATTANEO et al. 1998, HiLt et al. 2010). Some studies suggested that biotic factors, competition and predation, have a significant influence on epiphyton distribution (WALSH 1995, LAUGUSTE and REUNANEN 2005). Thus far epiphyton community ecology has received less attention than plankton communities, despite the diversity and density, probably due to methodological problems regarding quantitative sampling, which is not standardized (DugGan 2001).

Our study was carried out in two shallow, eutrophic lakes with narrow macrophyte belts. Previous study in these lakes suggested that differences in transparencies between two lakes caused significant differences in horizontal distribution of the zooplankton assemblage. Even narrow helophyte belts offered a refuge to zooplankton, although lower transparencies reduced the effectiveness of macrophytes as a refuge from predators (ŠPOLJAR et al. 2011). The present study aims to explore the effects of the water transparency and its derived trophic state index as well as effects of macrophyte species on 
epiphytic metazoans diversity and density. Concordantly, our goals were to analyse: (i) impact of environmental parameters and food resources on epiphyton; (ii) influence of different macrophyte architecture on the epiphytic metazoan assemblage. We presume that results of this study will reveal epiphytic metazoans to be an adequate indicator of eutrophication and change in environmental conditions.

\section{Study area}

The main features of the two oxbow lakes on the Krapina River (NW Croatia) were well documented in a previous paper (ŠPOLJAR et al. 2011). Both lakes were formed by river-straightening operations and are situated approximately $500 \mathrm{~m}$ apart (Fig. 1). No submerged macrophytes were present on the bottom, which consists of alluvial silt substrate. The water level depends mainly on precipitation and groundwater, with the lowest levels being recorded in the summer. The location, morphometric features and macrophyte composition of each of the lakes, Krapina Oxbow Lake 1 (KO1) and Krapina Oxbow Lake

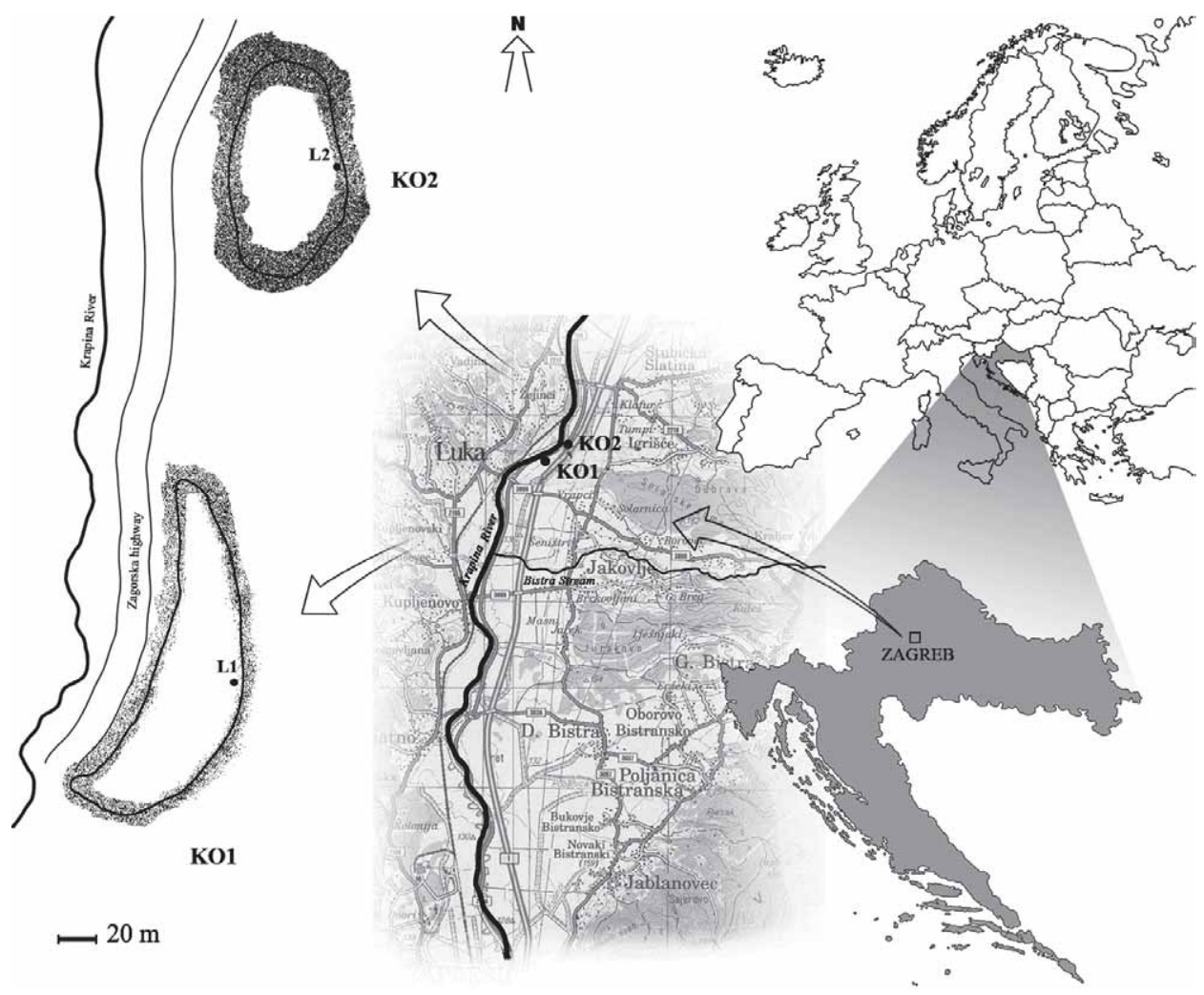

Fig. 1. Map of the investigated Krapina River oxbow lakes (KO1 and KO2), showing study sites in littoral zones (L1 and L2). In L1 Iris stems were sampled (habitat I1) and in L2 Iris (habitat I2) and Mentha (M2) stems were sampled. 
2 (KO2), are summarized in table 1a. Lake KO1 had significantly higher conductivity and algal biomass but lower transparency, $\mathrm{pH}$ and percentage of macrophyte cover than lake KO2 (ŠPOLJAR et al. 2011). On each sampling occasion, epiphyton samples were collected from the littoral zone of each lake (L1 in KO1 and L2 in KO2). Environmental conditions in L1 and L2 are shown in table 1b. In the two oxbow lakes, the fish communities were

Tab. 1. a) Main morphometric features, macrophyte composition and significantly different environmental parameters of the studied Krapina oxbow lakes KO1 and KO2 (source ŠPOLJAR et al. 2011); b) mean values of environmental parameters on the investigated study sites L1 and L2 (mean \pm SD).

\begin{tabular}{|c|c|c|}
\hline \multicolumn{3}{|l|}{ a) } \\
\hline Parameters & KO1 & $\mathrm{KO} 2$ \\
\hline Coordinates & $45^{\circ} 57^{\prime} 96^{\prime \prime} \mathrm{N} ; 15^{\circ} 50^{\prime} 78^{\prime \prime} \mathrm{E}$ & $45^{\circ} 57^{\prime} 37^{\prime \prime} \mathrm{N} ; 15^{\circ} 50^{\prime} 63^{\prime \prime} \mathrm{E}$ \\
\hline Length $_{\max }(\mathrm{m})$ & 150 & 81 \\
\hline Width $_{\text {mean }}(\mathrm{m})$ & 37 & 48 \\
\hline Surface area (ha) & 1.7 & 1.0 \\
\hline Max. depth (m) & 4.0 & 3.0 \\
\hline Shore slope & steep & gradual \\
\hline Transparency $_{S D}(\mathrm{~m})$ & $0.3-1.1$ & $0.6-1.2$ \\
\hline $\mathrm{pH}$ & $7.12-7.41$ & $7.13-7.75$ \\
\hline Conductivity $\left(\mu \mathrm{S} \mathrm{cm}^{-1}\right)$ & $345-404$ & $285-325$ \\
\hline Chl $a\left(\mathrm{mg} \mathrm{m}^{-3}\right)$ & $1.18-23.38$ & $2.37-10.65$ \\
\hline Macrophyte coverage \% & $3.2-5.5$ & $5.0-7.8$ \\
\hline Surronding area & ploughed-fields & meadows \\
\hline Macrophyte type & emergent & emergent \\
\hline \multirow[t]{4}{*}{ Macrophyte composition (\%) } & Typha latifolia (40\%) & Typha latifolia (40\%) \\
\hline & Iris pseudacorus (30\%) & Iris pseudacorus (20\%) \\
\hline & Carex sp. $(15 \%)$ & Carex sp. (15\%) \\
\hline & Sparganium ramosum $(15 \%)$ & Mentha aquatica (25\%) \\
\hline \multicolumn{3}{|l|}{ b) } \\
\hline & L1 & $\mathrm{L} 2$ \\
\hline Parameters & Mean \pm SD & Mean \pm SD \\
\hline Temperature $\left({ }^{\circ} \mathrm{C}\right)$ & $20.7 \pm 4.4$ & $22.2 \pm 4.5$ \\
\hline Dissolved oxygen $\left(\mathrm{mg} \mathrm{L}^{-1}\right)$ & $6.2 \pm 2.4$ & $7.6 \pm 2.9$ \\
\hline Conductivity $\left(\mu \mathrm{S} \mathrm{cm}^{-1}\right)^{*}$ & $370.4 \pm 18.3$ & $302.9 \pm 11.7$ \\
\hline $\mathrm{pH} *$ & $7.26 \pm 0.09$ & $7.48 \pm 0.13$ \\
\hline Alkality (mg L $\left.{ }^{-1}\right)$ & $111.1 \pm 4.9$ & $113.3 \pm 5.6$ \\
\hline Nitrate $\left(\mathrm{mg} \mathrm{N}-\mathrm{NO}_{3}{ }^{-} \mathrm{L}^{-1}\right)$ & $0.344 \pm 0.52$ & $0.338 \pm 0.51$ \\
\hline Orthophospate (mg P-PO ${ }_{4}^{3-} \mathrm{mg} \mathrm{L}^{-1}$ ) & $0.026 \pm 0.01$ & $0.025 \pm 0.01$ \\
\hline Chl $a\left(\mathrm{mg} \mathrm{m}^{-3}\right)$ & $11.2 \pm 3.81$ & $6.5 \pm 3.0$ \\
\hline $\operatorname{AFDW}\left(\mathrm{mg} \mathrm{m}^{-3}\right)$ & $1809 \pm 1388$ & $8324 \pm 10103$ \\
\hline
\end{tabular}

$n_{\mathrm{L}, \mathrm{L} 1}=9$; * significant difference $\mathrm{P}<0.05$ 
similar (MraKovČIć and MarČIĆ 2006). Among fish present species carp prevailed (Cyprinus carpio) followed by black bullhead (Ameiurus melas), pike (Esox lucius), pikeperch (Sander lucioperca), roach (Rutilus rutilus), bleak (Alburnus alburnus), bream (Abramis brama), sunfish (Lepomis gibbosus) and chub (Squalius cephalus).

\section{Materials and methods}

All measurements and sampling related to environmental variables, food resources and epiphyton were collected between April and October 2008. Two seasons were considered in the analyses: spring (April-June) and summer (July-September). In September the water level was low and emergent macrophyte belts were above the water level and thus epiphyton samples could not be taken. Samples were collected at monthly intervals, whereas in May, June and July, samples were collected twice per month.

We sampled macrophytes on the east bank of each oxbow lake, as that side was flooded for a longer period than the others. On these sites only Iris pseudacorus and Mentha aquatica were present. Iris contains sword-shaped leaves tightly packed at the base, while Mentha has a square stem with alternating opposite pairs of leaves. Epiphyton was sampled from these two macrophyte species, differing in their habitus architecture: simple, i.e., Iris pseudacorus in the littoral zone of both lakes (I1 in L1 and I2 in L2) and complex, i.e., Mentha aquatica (M2), only in L2. Triplicate samples of each species and site (each sample included a single plant) were taken with a plastic hand cylinder sampler $(30 \mathrm{~cm}$ high, diameter $8 \mathrm{~cm}$, mesh net $26 \mu \mathrm{m}$ ) according to KoRNIJów and KAIRESALO (1994). Epiphyton sampling was provided by cutting submerged part of macrophytes into 10 to $15 \mathrm{~cm}$ long parts, which were scraped using a small brush, rinsed with distilled water, collected and transported in plastic bottles to the laboratory. Pertaining macrophyte stems were deposited in other bottles and brought to the laboratory, where dry mass (DM) was measured after drying in a thermostat at $60{ }^{\circ} \mathrm{C}$ for $24 \mathrm{~h}$ (CATTANEO et al. 1998). Parallel with epiphyton sampling another set of triplicate macrophyte parts was taken for determination of algal biomass in epiphyton..

Specimens of epiphytic metazoans were determined and counted on live material under an Opton-Axiovert 35 inverted microscope (100 to 450×). Before counting the whole sample was thoroughly mixed in order to achieve homogenous distribution of specimens. The entire volume (c. $5 \mathrm{~mL}$ ) of collected epiphyton was counted in a Petri dish under an inverted microscope. In the case of high density, half of the sample was checked, and counting was adjusted for the entire sample. For species determination, we consulted the following monographs: Koste (1978) Rotifera, Einsle (1993) Copepoda and MARgaritorA (1983) Cladocera. Bdelloidea were counted, but not identified, and densities of Polyarthra dolichoptera and Polyarthra vulgaris were aggregated into a single category (Polyarthra spp.). Cladocera were divided into two groups according to the body size: small-bodied (length $500 \mu \mathrm{m}$ to $1 \mathrm{~mm}$ ) and large-bodied (length $>1 \mathrm{~mm}$ to $6 \mathrm{~mm}$ ). Epiphyton assemblages for each station and each month were quantified as density and were expressed as the number of individuals per $1 \mathrm{~g}$ of macrophyte dry mass. After metazoan specimens counting, samples were used for determination of epiphyton ash free dry mass (AFDMe). These data were obtained after drying of each sample at $104{ }^{\circ} \mathrm{C}$ for $4 \mathrm{~h}$ in ceramic dishes and ashing at $600{ }^{\circ} \mathrm{C}$ for $6 \mathrm{~h}$. 
All physicochemical measurements (alkalinity, concentrations of nitrate and orthophosphate) as well as records related to investigated area and the period of investigation were presented in the study by ŠPOLJAR et al. (2011). Algal biomass (measured as chlorophyll $a$, $\mathrm{Chl} a$ ) and detritus or particulate organic matter, POM (measured as ash free dry mass, AFDM) were considered to be possible food resources in plankton and epiphyton. Chl $a$ in epiphyton ( $\mathrm{Chl} a$ ) was determined using an ethanol extraction method by NUSCH (1980).

Macrophyte coverage (\%) was estimated from the ratio of transect length occupied by macrophytes to total transect length at five locations in each lake (LAU and LANE 2002). Similarity among epiphyton samples was calculated using the Sørensen index (SI) according to equation $\mathrm{SI}=2 \mathrm{C} / \mathrm{A}+\mathrm{B}$, where $A$ and $B$ are the number of species in samples $\mathrm{A}$ and $\mathrm{B}$, respectively, and $C$ is the number of species shared by the two samples (SøRENSEN 1948). According to the Secchi disc transparency, we calculated trophic state index and distinguished trophic states by CARLSON (1977). Rotifera and Cladocera density in littoral water was computed from the study ŠPOLJAR et al. (2011). In further analyses the mean of triplicate samples was used as a single data point for a given date and site. Prior to statistical analysis, all biotic and abiotic parameters were logarithmically transformed $[\log (\mathrm{x}+1)]$ and their normality was checked using Shapiro-Wilk's test. As this test suggested that the data did not follow a normal distribution, even after transformation ( $p>0.05)$, a nonparametric Kruskal-Wallis test (comparison between multiple habitats) and Mann-Whitney U test (comparison between two seasons) were used.

\section{Results}

According to trophic state index mean value (67 \pm 5.5$)$ in KO1 highly eutrophic conditions prevailed while in $\mathrm{KO} 2$ values were much lower $(38 \pm 5.3)$ which suggested mesotrophic conditions (Fig. 2). These values significantly varied between the two oxbow lakes

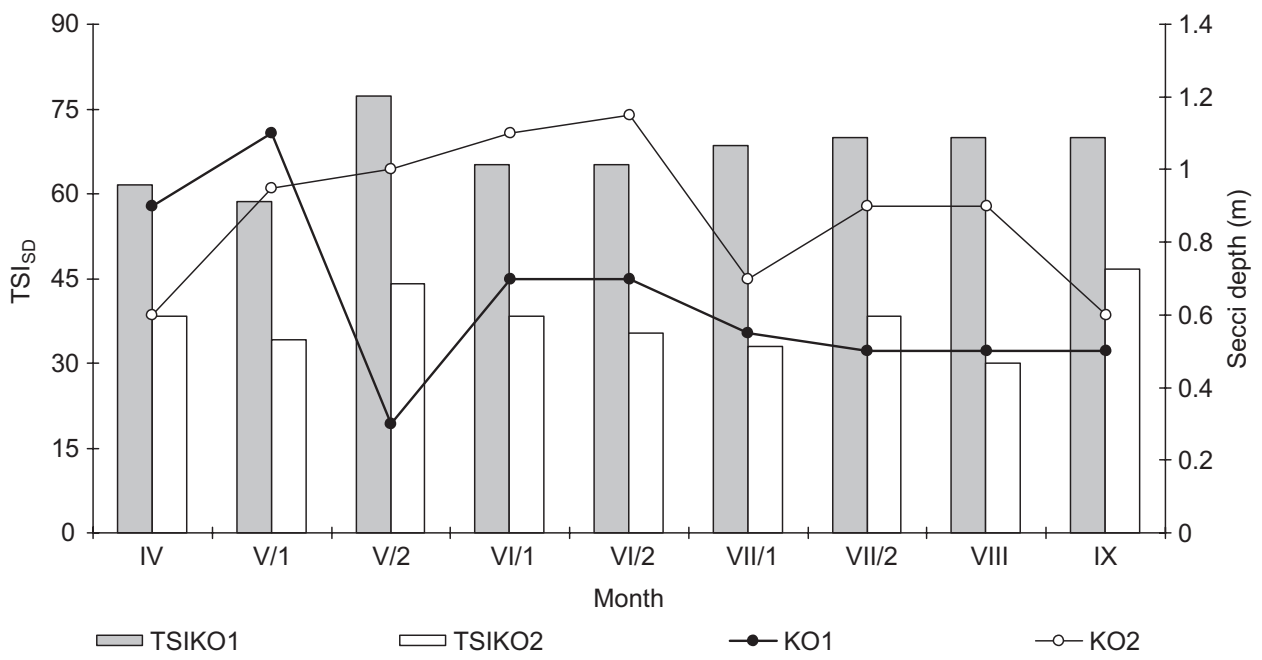

Fig. 2. Seasonal oscillations of transparency and trophic state index $\left(\mathrm{TSI}_{\mathrm{SD}}\right)$ in two Krapina River oxbow lakes (KO1 and $\mathrm{KO} 2)$. 
$(\mathrm{Z}=3.59, \mathrm{n}=18, \mathrm{p}=0.0003)$. Further results of analyses suggested that epiphytic metazoan diversity and cladoceran density increased at higher transparency (Tab. 2). These interactions were also significant particularly on $\mathrm{M} 2$ ( $\mathrm{r}=0.84$ to $0.89, \mathrm{n}=8, \mathrm{p}<0.05)$. Ash free dry mass was deposed significantly more $(\mathrm{p}<0.05)$ on I1 than on I2 and M2 (Fig. 3a), and significantly negatively correlated with biodiversity, higher rotifer and total metazoans density in epiphyton (Tab. 2). Algal biomass ( $\mathrm{Chl} a$ ) did not oscillate significantly in macrophyte epiphyton during the investigated period (Fig. 3b). It had a significant and positive relation with rotifer and total metazoan density in epiphyton (Tab. 2). Also, two oxbow lakes were significantly different in $\mathrm{pH}$ values $(\mathrm{Z}=-3.04, \mathrm{n}=18, \mathrm{p}=0.002)$ and conductivity $(\mathrm{Z}=3.58, \mathrm{n}=18, \mathrm{p}=0.0003$ ) (Tab. 1b). Among DM and nutrients, as well as between epiphytic community and environmental parameters in the surrounding water, no significant correlations were established ( $\mathrm{p}>0.05)$.

A total of 48 epiphytic metazoan taxa were recorded in this study, where rotifers prevailed in diversity (38 taxa) and density (70\%). Habitats I2 and M2 (each 41 taxa) had significantly higher diversity than I1, where only 16 taxa were recorded (Fig. 2c, Tab. 3). Sørensen similarity index between epiphytic metazoans at different sampling sites (I1 and I2 42\%; I1 and M2 38\%) was lower than between different macrophytes at the same sampling site (I2 and M2 75\%).

Density of epiphytic metazoans as well as densities of rotifers and copepods in epiphyton reached significantly higher values on M2 compared to I1 (Fig. 3d, f, g). Total density

Tab. 2. Significant Spearman correlations $(\mathrm{p}<0.05)$ between food resources and biotic parameters $(n=24)$. AFDMe - ash free dry mass.

\begin{tabular}{|c|c|c|c|c|c|}
\hline & $\begin{array}{l}\text { g AFDM } \\
\mathrm{g}^{-1} \mathrm{DM}\end{array}$ & $\begin{array}{l}\mu \mathrm{g} \mathrm{Chl} a \\
\mathrm{~g}^{-1} \mathrm{DM}\end{array}$ & $\begin{array}{c}\text { Epiphytic } \\
\text { metazoans } \\
\text { species richness } \\
\text { (number of taxa) }\end{array}$ & $\begin{array}{l}\text { Total epiphytic } \\
\text { metazoans } \\
\text { abundance } \\
\text { (ind. } \mathrm{g}^{-1} \mathrm{DM} \text { ) }\end{array}$ & $\begin{array}{l}\text { Cladocerans } \\
\text { abundance in } \\
\text { epiphyton } \\
\text { (ind. } g^{-1} \mathrm{DM} \text { ) }\end{array}$ \\
\hline Transparency (SD m) & & & 0.47 & & 0.66 \\
\hline $\begin{array}{l}\text { Epiphytic metazoans } \\
\text { species richness } \\
\text { (number of taxa) }\end{array}$ & -0.71 & & & & 0.49 \\
\hline $\begin{array}{l}\text { Total epiphytic } \\
\text { metazoans abundance } \\
\text { (ind. } \mathrm{g}^{-1} \mathrm{DM} \text { ) }\end{array}$ & -0.51 & 0.43 & & & 0.47 \\
\hline $\begin{array}{l}\text { Rotifera abundance } \\
\text { in epiphyton } \\
\text { (ind. } \mathrm{g}^{-1} \mathrm{DM} \text { ) }\end{array}$ & -0.42 & 0.46 & & 0.94 & \\
\hline $\begin{array}{l}\text { Copepoda abundance } \\
\text { in epiphyton } \\
\text { (ind. } \mathrm{g}^{-1} \mathrm{DM} \text { ) }\end{array}$ & & & & 0.77 & 0.52 \\
\hline $\begin{array}{l}\text { Cladocera abundance } \\
\text { in plankton (ind. } \mathrm{L}^{-1} \text { ) }\end{array}$ & & & 0.41 & & 0.62 \\
\hline $\begin{array}{l}\text { Rotifera abundance in } \\
\text { plankton (ind. } \mathrm{L}^{-1} \text { ) }\end{array}$ & & & & & -0.45 \\
\hline
\end{tabular}



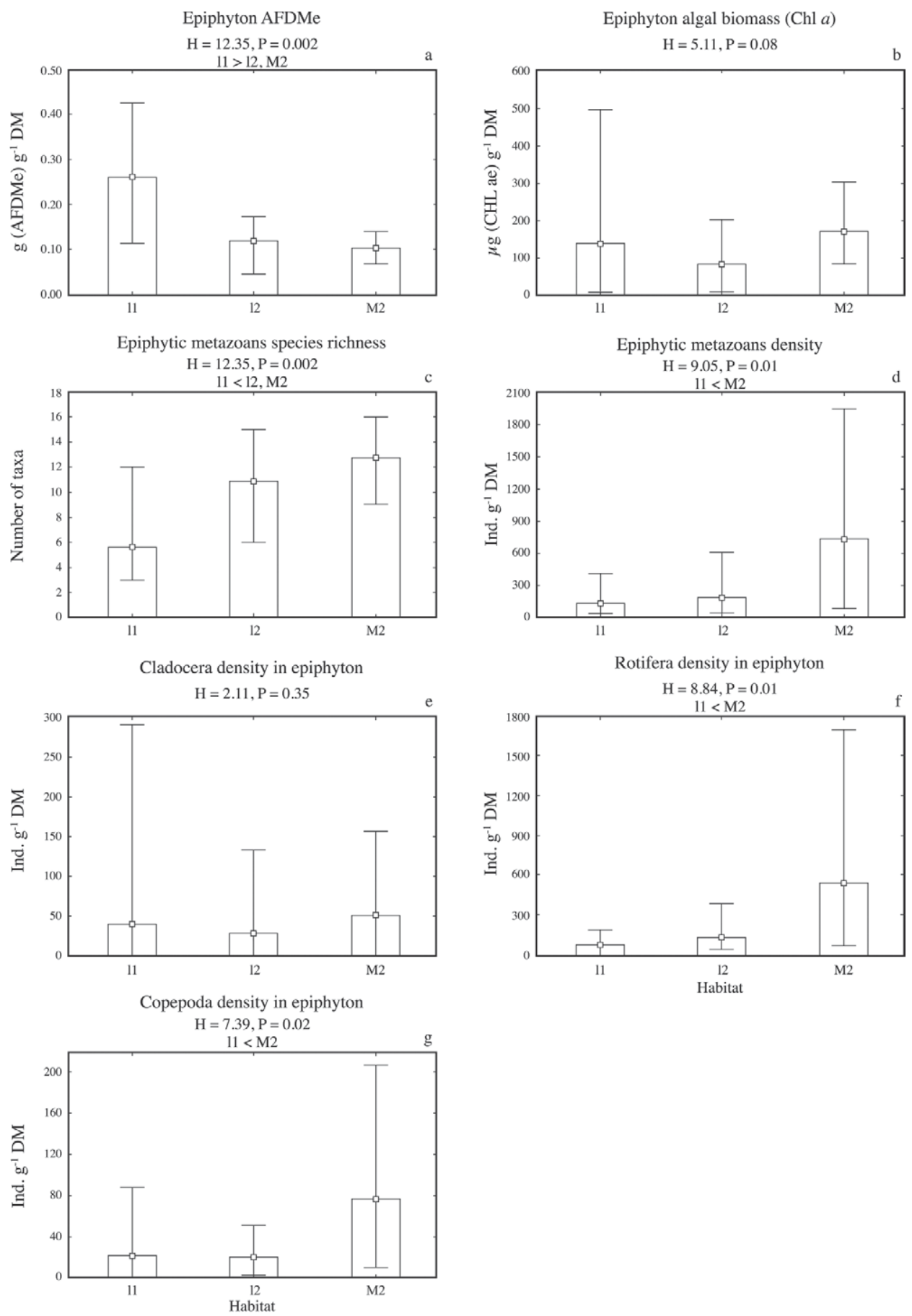

Fig. 3. Mean, minimum and maximum values of analysed parameters among different habitats. Results of significant differences among habitats according to Kruskal-Wallist test ( $d f=2, n=24)$ and post-hoc multiple comparison are incorporated in graph titles. 
Tab. 3. Mean densities (mean $\pm \mathrm{SD}, \mathrm{n}_{\mathrm{I} 1, \mathrm{I}, \mathrm{M} 2}=24$ ) of epiphytic metazoans at different habitats I1, I2 and M2.

\begin{tabular}{|c|c|c|c|c|c|c|c|c|c|c|}
\hline \multirow{2}{*}{$\overline{\text { Group }}$} & \multirow[b]{2}{*}{ Taxa } & \multicolumn{3}{|c|}{ I1 (Ind g ${ }^{-1} \mathrm{DM}$ ) } & \multicolumn{3}{|c|}{ I2 (Ind $\left.\mathrm{g}^{-1} \mathrm{DM}\right)$} & \multicolumn{3}{|c|}{ M2 (Ind $\left.{ }^{-1} \mathrm{DM}\right)$} \\
\hline & & Mean & & SD & Mean & & SD & Mean & & SD \\
\hline \multirow[t]{12}{*}{ Cladocera } & Acroperus elongatus (Sars, 1862) & & & & 0.2 & \pm & 1 & 1 & \pm & 4 \\
\hline & Alona costata Sars, 1862 & 38 & \pm & 102 & 2 & \pm & 4 & 1 & \pm & 3 \\
\hline & Alona rectangula Sars, 1862 & & & & 10 & \pm & 31 & & & \\
\hline & Alona weltneri Keilhack, 1905 & & & & 1 & \pm & 2 & 1 & \pm & 4 \\
\hline & Bosmina longirostris (O. F. Müller, 1776) & 2 & \pm & 3 & 7 & \pm & 9 & 16 & \pm & 26 \\
\hline & Ceriodaphnia laticaudata O. F. Müller, 1867 & & & & 1 & \pm & 2 & 2 & \pm & 5 \\
\hline & Ceriodaphnia quadrangula O. F. Müller, 1785 & & & & & & & 0.4 & \pm & 1 \\
\hline & Chydorus ovalis Kurz, 1875 & & & & 2 & & 3 & 18 & \pm & 26 \\
\hline & Chydorus sphaericus (O. F. Müller, 1776) & & & & 2 & \pm & 7 & 7 & \pm & 20 \\
\hline & Daphnia cuculata Sars, 1862 & & & & & & & 2 & \pm & 3 \\
\hline & Pleuroxus denticulatus Birge, 1879 & & & & 0.2 & \pm & 1 & & & \\
\hline & Scapholeberis kingi Sars, 1888 & & & & & & & 2 & \pm & 6 \\
\hline \multicolumn{2}{|c|}{ Cladocera total } & 40 & \pm & 102 & 25 & \pm & 43 & 51 & \pm & 57 \\
\hline \multirow[t]{2}{*}{ Copepoda } & copepodites & 5 & \pm & 10 & 2 & \pm & 7 & 6 & \pm & 13 \\
\hline & nauplii & 17 & \pm & 20 & 17 & \pm & 10 & 71 & \pm & 68 \\
\hline \multicolumn{2}{|c|}{ Copepoda total } & 22 & \pm & 29 & 20 & \pm & 14 & 77 & \pm & 73 \\
\hline Insecta & Diptera larvae & & & & 3 & \pm & 7 & 5 & \pm & 8 \\
\hline Nematoda & Nematoda & & & & 6 & \pm & 14 & 61 & \pm & 100 \\
\hline Ostracoda & Ostracoda & & & & 0.5 & \pm & 1 & 2 & \pm & 5 \\
\hline \multirow[t]{30}{*}{ Rotifera } & Ascomorpha saltans Bartsch, 1870 & 35 & \pm & 54 & 1 & \pm & 4 & & & \\
\hline & Asplanchna priodonta (Goose, 1850$)$ & 0.1 & \pm & 0.4 & 5 & \pm & 12 & 1 & \pm & 2 \\
\hline & Bdelloidea & & & & 36 & \pm & 91 & 9 & \pm & 17 \\
\hline & Brachionus angularis Goose, 1851 & 0.2 & \pm & 0.5 & & & & & & \\
\hline & Brachionus patulus (O. F. Müller, 1786) & & & & 6 & \pm & 12 & 2 & \pm & 4 \\
\hline & Brachionus quadridentatus Hermann, 1783 & & & & & & & 6 & \pm & 12 \\
\hline & Brachionus urceolaris O. F. Müller, 1773 & & & & & & & 33 & \pm & 93 \\
\hline & Cephalodella forficata (Ehrenberg, 1832) & 1 & \pm & 2 & & & & & & \\
\hline & Cephalodella gibba (Ehrenberg, 1832) & 0.1 & \pm & 0.4 & & & & 1 & \pm & 4 \\
\hline & Colurella obtusa (Goose, 1886) & & & & 10 & \pm & 27 & 126 & \pm & 208 \\
\hline & Colurella uncinata (O. F. Müller, 1773) & & & & & & & 1 & \pm & 4 \\
\hline & Filinia longiseta (Ehrenberg, 1834) & 0.1 & \pm & 0.4 & 2 & \pm & 3 & 24 & \pm & 41 \\
\hline & Gastropus stylifer Imhof, 1891 & & & & 5 & \pm & 12 & 4 & \pm & 9 \\
\hline & Keratella cochlearis $(\mathrm{Goose}, 1851)$ & 17 & \pm & 19 & 17 & \pm & 24 & 107 & \pm & 132 \\
\hline & Keratella cochlearis tecta Goose, 1851 & & & & 0.2 & \pm & 0.5 & & & \\
\hline & Keratella quadrata (O. F. Müller, 1786) & 1 & \pm & 1 & 10 & \pm & 19 & 12 & \pm & 19 \\
\hline & Lecane cornuta (Müller, 1786) & & & & 3 & \pm & 9 & 15 & \pm & 42 \\
\hline & Lecane luna (O. F. Müller, 1776) & 3 & \pm & 4 & 12 & \pm & 17 & 27 & \pm & 43 \\
\hline & Lecane lunaris (Ehrenberg, , 1832) & 5 & \pm & 10 & 24 & \pm & 43 & 55 & \pm & 74 \\
\hline & Lepadella patella (O. F. Müller, 1786) & & & & 8 & \pm & 20 & 4 & \pm & 6 \\
\hline & Ploesoma hudsoni (Ehrenberg, , 1891) & & & & 1 & \pm & 4 & 1 & \pm & 3 \\
\hline & Polyarthra spp. & 4 & \pm & 7 & 2 & \pm & 4 & 4 & \pm & 9 \\
\hline & Pompholyx sulcata Hudson, 1885 & & & & 7 & \pm & 19 & 3 & \pm & 9 \\
\hline & Scaridium longicaudum (Müller, 1786) & & & & 0.1 & \pm & 0.2 & 1 & \pm & 2 \\
\hline & Squatinella rostrum (Schmarda, 1846) & & & & 0.2 & \pm & 1 & 15 & \pm & 44 \\
\hline & Squatinella lamellaris (O. F. Müller, 1786) & & & & 0.2 & \pm & 1 & & & \\
\hline & Testudinella mисronata (Goose, 1886) & & & & 1 & \pm & 3 & 59 & \pm & 140 \\
\hline & Trichocerca bicristata (Goose, 1887) & 1 & \pm & 2 & 1 & \pm & 2 & 6 & \pm & 14 \\
\hline & $\begin{array}{l}\text { Trichocerca capucina (Wierzejski et } \\
\text { Zacharias, 1893) }\end{array}$ & & \pm & & 1 & \pm & 2 & & & \\
\hline & Trichocerca longiseta (Schrank, 1802) & 2 & \pm & 3 & 6 & \pm & 8 & 18 & \pm & 16 \\
\hline \multicolumn{2}{|c|}{ Rotifera total } & 67 & \pm & 56 & 160 & \pm & 160 & 537 & \pm & 570 \\
\hline \multicolumn{2}{|l|}{ Grand total } & 128 & \pm & 124 & 216 & \pm & 205 & 733 & \pm & 654 \\
\hline
\end{tabular}


of epiphytic metazoans was significantly positively affected by rotifers and copepods density (Tab. 2). Separately, on habitat M2 rotifer abundance significantly positively affected epiphytic metazoan abundance $(\mathrm{r}=0.95, \mathrm{n}=8, \mathrm{p}<0.05)$. In general, prevailing among epiphytic rotifers were the microphagous species, Keratella cochlearis, Lecane lunaris and Colurela obtusa. Cladoceran density in epiphyton did not show significant differences ( $p>0.05$ ) among investigated habitats (Fig. 3e). Their epiphytic abundance was positively affected by cladocerans in surrounding water and negatively by rotifer density in surrounding water (Tab. 2). Small-bodied microphagous cladocerans i.e., Alona, Bosmina and Chydorus species contributed mostly in total epiphytic metazoan density (Tab. 3). Among cladocerans in M2, the presence of large-bodied (i.e. Daphnia, Ceriodaphnia) and of small-bodied species (Tab. 3) was recorded. Copepods, represented by nauplii and copepodites, also reached their highest density on M2 (Fig. 3g). Among studied epiphytic metazoans only copepod density in epiphyton showed a significant difference $(Z=2.21$, $\left.n_{\text {spring,summer }}=8, \mathrm{p}=0.03\right)$ in seasonality with higher density in spring $\left(46 \pm 50\right.$ ind. $\left.\mathrm{g}^{-1} \mathrm{DM}\right)$ and lower in summer $\left(28 \pm 56\right.$ ind. $\left.\mathrm{g}^{-1} \mathrm{DM}\right)$.

\section{Discussion}

Transparency is a well known indicator of the trophic state in aquatic systems (KARABIN 1985) and a main driver in the outcome of predator-prey relations (HORPILA and NURMINEN 2005, ESTLANDER et al. 2009). We assume that more intensive agriculture on ploughed fields and fishing around/in $\mathrm{KO} 1$ than $\mathrm{KO} 2$ contribute to decreased transparency via increasing particulate and dissolved organic matter indicating eutrophic conditions in lake KO1. Significantly lower $\mathrm{pH}$ and higher conductivity in the higher trophic lake, KO1, indicate phosphorous release from sediment at lower $\mathrm{pH}$, which leads simultaneously to increasing ionic concentration measured as electroconductivity (review KALFF 2002). BIELAŃSKA-GRAJNER and GŁADYSZ (2010) also concluded that higher electroconductivity often cooccurs with anthropogenic eutrophication reflected as higher trophic levels.

Results of analyses in this study suggested that transparency positively influenced cladoceran diversity and density, as well as total metazoan diversity in epiphyton. This could be explained by intensive fish predation at higher transparency in pelagial, with cladocerans migrating to the littoral and becoming attached to macrophytes (NURMINEN et al. 2007, ESTLANDER et al. 2009). Similar results were established in previous study in these oxbow lakes as increasing density of small and large-bodied cladocerans in littoral zone of KO2 at higher transparency in the pelagial (ŠPOLJAR et al. 2011).

We recorded the highest value of organic matter in epiphyton on a simple Iris stem in KO1. This could be explained by the decreasing role of macrophytes as shelter for zooplankton at a higher trophic level, as water turbidity increased and transparency decreased (CASTRO et al. 2005, EstLANDER et al. 2009). Thus Iris belt in KO1 was not a favourable habitat for epiphytic metazoans and consequently low grazing on algae and detritus was expressed as higher AFDMe. Results of correlations suggested decreasing AFDMe amount at higher epiphytic metazoan density and diversity, especially caused by higher rotifers density. It indicated metazoans grazing upon detritus in epiphyton and the development of few abundant microphagous species among rotifers (bdelloids, Colurella, Lecane) (review, MACINnIS 1997) and cladocerans (Alona, Bosmina, Chydorus) (HART and Lovvorn 2000, CAZZANElli et al. 2008). 
Algal biomass in epiphyton did not vary significantly among the investigated macrophytes. Thus our results do not confirm the results of other authors that macrophytes with complex architecture harbour a higher amount of epiphyton (DUGGAN 2001, TESSIER et al. 2008). We explain our results on assessment that Mentha surface area does not exceed that of Iris. This is expressed in similar epiphytic algal biomass between habitats and sites. Positive relation between algal biomass and epiphytic metazoans and rotifer densities could be explain by the feeding guilds of these organisms. As microphagous species dominated in epiphyton, we suppose that they influenced the grazing of organic matter. Rotifer (Ascomorpha, Gastropus, Trichocerca) and crustacean (nauplii, copepodites, Daphnia) algivorous species just temporarily fed on epiphyton and did not significantly influence on algal grazing (ARMENGOL and MiracLe 2000, HorpPila and Nurminen 2008).

We think that in our study different densities among epiphytic metazoans were not derived from plant architecture but from interaction between width of macrophyte belt and turbidity in each lake. For instance, Iris stems in the less transparent and higher trophic lake, KO1, hosted significantly fewer species than Iris stems in the lake of higher transparency and lower trophic state, $\mathrm{KO} 2$. In KO1 the macrophyte belt is significantly narrower than in KO2 (ŠPOLJAR et al. 2011). These results indicate that higher turbidity and trophic level together with narrow macrophyte belt probably reduce the influence of macrophyte belt as a zooplankton shelter against predators (ESTLANDER et al. 2009, ŠPOLJAR et al. 2011). In lake $\mathrm{KO} 2$, Iris and Mentha recorded equal total diversity of epiphytic metazoans. However, species composition indicates that Mentha epiphyton hosted some large-bodied cladocerans, i.e. Ceriodaphia, Daphnia, while on Iris small-bodied cladocerans were attached. This is in agreement with records that macrophytes of complex architecture offer better shelter than those with simple architecture (VIEIRA et al. 2007). Namely, large-bodied cladocerans are first under attack from fish predators and need safe shelter against fish (BALAYLA and Moss 2003, CAZZANELli et al. 2008). Thereby, significant correlations among diversity and cladoceran density in Mentha epiphyton derived presumably from a wider macrophyte belt in $\mathrm{KO} 2$ than in $\mathrm{KO} 1$. Moreover, total epiphyton diversity positively correlated with cladoceran density.

We presumed that at higher transparency, i.e. KO2, there was an increased risk of fish predation, which caused copepods to shift to the littoral zone, where they found more complex Mentha a more suitable habitat provided by simple Iris. This resulted in significant differences in their spatial distribution which is in accord with results of MIRACLE et al. (2007).

As in other studies (DugGan et al. 2001, Arora and MeHra 2003), rotifers contributed most to the total density in epiphyton at each habitat. Taxa restricted to vegetation, bdelloids and Lecane, but also Keratella cochlearis mainly contributed to this higher density. The latter species is characterised as common in vegetation and open water. In the more complex Mentha habitat $K$. cochlearis developed a higher density, in contrary to the more simple Iris habitat.

According to ROMARE et al. (2003) the littoral zone and its connection with the pelagial is important in structuring fish and plankton assemblage. The epiphyton community could also indicate the consequences of environmental and biocoenotic changes. A better insight would be revealed by further comprehensive studies of aquatic communities. 


\section{References}

Armengol, X., Miracle, M. R., 2000: Diel vertical movements of zooplankton in lake La Cruz (Cuenca, Spain). Journal of Plankton Research 22, 1683-1703.

Arora, J., MeHRA, N. K., 2003: Species siversity of planctonic and epiphytic rotifers in the backwaters of the Delhi segment of the Yamuna river, with remarks on new rwcords for India. Zoological studies 42, 239-247.

Balayla, D. J., Moss, B., 2003: Spatial patterns and population dynamics of plant-associated microcrustacea (Cladocera) in an English shallow lake (Little Mere, Cheshire). Aquatic ecology 37, 417-435.

BeCERRA-MunOz, S., Schramm Jr., H. L., 2007: On the influence of substrate morphology and and surface area on phytofauna. Hydrobiologia 575, 117-128.

BielańsKa-Grajner, I. Gladysz, A., 2010: Planktonic rotifers in mining lakes in the silesian upland: relationship to environmental parameters. Limnologica 40, 67-72.

Bogut, I., ČERBA, D., Vidaković, J., Gvozdić V., 2010: Interactions of weed-bed invertebrates and Ceratophyllum demersum stands in a floodplain lake. Biologia, Bratislava 65, 113-121.

CARLson, R. E., 1977: A trophic state index for lakes. Limnology and Oceanography 22, 361-369.

Castro, B. B., Antunes, S. C., Pereira, R., Soares, A. M. V. M., Gonçalves S. F., 2005 : Rotifer community structure in three shallow lakes: seasonal fluctuations and explanatory factors. Hydrobiologia 543, 221-232.

Cattaneo, A., Galanti, G., Gentinetta, S., Romo, S., 1998: Epiphytic algae and macroinvertebrates on submerged and floating-leaved macrophytes in an Italian lake. Freshwater Biology 39, 725-740.

Cazzanelli, M., Warming, T. P., Christoffersen, K. S., 2008: Emergent and floating-leaved macrophytes as refuge for zooplankton in a eutrophict temperate lake without submerged vegetation. Hydrobiologia 605, 113-122.

Chambers, P. A., Lacoul, P., Murphy, K. J., Thomaz, S. M., 2008: Global diversity of aquatic macrophytes in freshwater. Hydrobiologia 595, 9-26.

DugGan, I. C., 2001: The ecology of periphytic rotifers. Hydrobiologia 446/447, 139-148.

Duggan, I. C., Green, J. D., Thompson, K., Shiel, R. J., 2001: The influence of macrophytes on the spatial distribution of littoral rotifers. Freshwater Biology 46, 777-786.

EInsle, U., 1993: Crustacea, Copepoda, Calanoida und Cyclopoida. Gustav Fischer Verlag, Berlin.

Estlander, S., NuRminen, L., Olin, M., VinNi, M., HorpPILA, J., 2009: Seasonal fluctations in macrophyte cover and water transparency of four brown-water lakes: implications for crustacean zooplankton in littoral and pelagic habitats. Hydrobiologia 620, 109-120.

Hart, E. A., Lovvorn, J. R. 2000: Vegetation dynamics and primary production in saline, lacustrine wetlands of a Rocky Mountain basin. Aquatic Botany 66, 21-39.

Hilt, S., Gross, E.M., Hupfer, M., Morscheid, H., Mählmann, J., Melzer, A., Poltz, J., SAndrock, S., Scharf, E.-M., Schneider, S., VAn De WeYer, K., 2006: Restoration of submerged vegetation in shallow eutrophic lakes - a guideline and state of the art in Germany. Limnologica 36, 155-171. 
Hilt, S., Henschke, I., RÜCKer, J., Nixdofr, B., 2010: Can submerged macrophytes influence turbidity and trophic state in deep lakes? Suggestions from a case study. Journal of Environmental Quality 39, 725-733.

Horppila, J., NuRMinEN, L., 2001: The effect of an emergent macrophyte (Typha angustifolia) on sediment resuspension in a shallow north temperate lake. Freshwater Biology 46, 1447-1455.

HorpPIlA, J., NuRminen, L., 2008: Diurnal variation in light intensity underneath floating macrophyte leaves and implications for the behaviour of plant-attached zooplankton. Biological Rhythm Research 39, 349-357.

Horppila, J., NuRMinEN, L., 2005: Effects of different macrophyte growth forms on sediment and $\mathrm{P}$ resuspension in a shallow lake. Hydrobiologia 545, 167-175.

Jeppesen, E., Jensen, J. P., SøndergaArd, M., LAuridsen T. L., 1999: Trophic dynamics in turbid and clearwater lakes with special emphasis on the role of zooplankton for water clatity. Hydrobiologia 408/409, 217-231.

Jeppesen, E., Søndergaard, M., Søndergaard, M., Christoffersen, K., Theil-Nielsen, J., JÜRGENS, K., 2002: Cascading trophic interactions in the littoral zone: an enclosure experiment in shallow Lake Stigsholm, Denmark. Fundamental and Applied Limnology - Archiv für Hydrobiologie 153, 533-555.

Joniak, T., KuCZyńskA-KipPEn, N., NAgengast, B., 2007: The role of aquatic macrophytes in microhabitual transformation of physical-chemical features of small water bodies. Hydrobiologia 584, 101-109.

KALFF, J., 2002: Limnology: Inland water ecosystems. Prentice Hall, Upper Saddle River, New Jersey.

KARABIN, A., 1985: Pelagic zooplankton (Rotatoria + Crustacea) variations in the process of lake eutrophication. I. Structural and quantitative features. Ekologia Polska 33, 567-616.

KlAASSEN, M., NolEt, B. A., 2007: The role of herbivorous water birds in aquatic systems through interactions with aquatic macrophytes, with special reference to the Bewick's Swan - Fennel Pondweed system. Hydrobiologia 584, 205-213.

KöHler, J., Hilt, S., Adrian, R., Nicklisch, A., Kozerski, H. P., Walz, N., 2005: Long-term response of a shallow, moderately flushed lake to reduced external phosphorus and nitrogen loading. Freshwater Biology 50, 1639-1650.

KorniJów, R., KAIRESALO, T., 1994: A simple apparatus for sampling epiphytic communities associates with emergent macrophytes. Hydrobiologia 294, 141-143.

Koste, W., 1978: Die Rädertiere Mitteleuropas. Gebrüder Borntraeger. Berlin, Stuttgart

KuCZYŃSKA-KipPen, N., KLIMASZYK, P., 2007: Diel distribution of physical and chemical parameters within the dense Chara bed and their impact on zooplankton. Biologia, Bratislava 62, 432-437.

Laguste, R., Reunanen, M., 2005: The composition and density of epiphyton on some macrophyte species in the partly meromictic Lake Verevi. Hydrobiologia 547, 137-150.

LAU, S. S. S., LANE, S. N., 2002: Nutrient and grazing factors in relation to phytoplankton level in a eutrophic shallow lake: the effect of low macrophyte abundance. Water Research 36, 3593-3601.

MACINNIS, M., 1997: Grazer control of bacterial abundance in a freshwater pond community. MSc Thesis, University of British Columbia. 
Margaritora, F., 1983: Cladoceri (Crustacea: Cladocera). Guide per il reconoscimiento delle specie animali delle acque interne, 22. Consiglio Nazionale delle Ricerche, Roma.

Meerhoff, M., Iglesias, C., Teixeira De Mello, F., Clemente, J. M., Jensen E., LauridSEN, T. L., JEPPESEN, E., 2007: Effects of habitat complexity on community structure and predator avoidance behavior of littoral zooplankton in temperate versus subtropical shallow lakes. Freshwater Biology 52, 1009-1021.

Miracle, M. R., Alfonso, M. T., Vicente, E., 2007: Fish and nutrient enrichment effects in a Mediterranean shallow lake: a mesocosm experiment. Hydrobiologia 593, 77-94.

MraKovČIĆ, M., MARČIć, Z., 2006: Fishery management plan and improvement measures for the freshwater fishery area »Šaran« Zaprešić (In Croatian). University of Zagreb, Zagreb.

Moss, B., Madgewick, J., Philis, G., 1997: A guide to therestoration of nutrient-enriched shallow lakes. WW Hawens, UK.

Nurminen, L., Horppila, J., PeCKan-Hekim, Z., 2007: Effect of light and predator abundance on the habitat choice of plant-attached zooplankton. Freshwater Biology 52, 539-548.

Nusch, E. A., 1980: Comparison of different methods for chlorophyll and phaeopigment determination. Archiv für Hydrobiologie-Beiheft Ergebnisse der Limnologie 14, 14-36.

Romare, P., Berg, S., Lauridsen, T., JePPesen, E., 2003: Spatial and temporal distribution of fish and zooplankton in a shallow lake. Freshwater Biology 48, 1353-1362.

Scheffer, M., Hosper, S.H., Meijer, M.-L., Moss, B., Jeppesen, E., 1993: Alternative equilibria in shallow lakes. Trends in Evolution and Ecology 8, 275-279.

Søndergaard, M., Jeppesen, E., Lauridsen, T. L., Skov, C., Van Nes, E. H., Roijackers, R., Lammens, E., Portielje, R., 2007: Lake restoration: successes, failures and long-term effects. Journal of Applied Ecology 44, 1095-1105.

SøRENSEN, T., 1948: A method of establishing groups of equal amplitude in plant sociology based on similarity of species and its application to analyses of the vegetation on Danish commons. Biologiske Skrifter 5, 1-34.

Špoljar, M., DražIna, T., Habdija, I., Meseljević, M., GrČIĆ, Z., 2011: Contrasting zooplankton assemblages in two oxbow lakes with low transparencies and narrow emergent macrophyte belts (Krapina River, Croatia). International Review of Hydrobiology 96, 175-190.

Tessier, C., Cattaneo, A., Pinel-Alloul, B., Hudon, C., Bocard, D., 2008: Invertebrate communities and epiphytic biomass associated with metaphyton and emergent and submerged macrophytes in a large river. Aquatic Sciences 70, 10-20.

Vieira, L. C. G., Bini, L. M., Velho, L. F. M., MAZAO, G. R., 2007: Influence of spatial complexity on the density and diversity of periphytic rotifers, microcrustaceans and testate amoebae. Fundamental and Applied Limnology - Archiv für Hydrobiologie $170,77-85$.

WaLsh, E. J., 1989: Ovoposition behaviour of the littoral rotifer Euchlanis dilatata. Hydrobiologia 186/187, 157-161.

WALSH, E. J., 1995: Habitat specific predation susceptibilities of a littoral rotifer to two invertebrate predators. Hydrobiologia 313/314, 205-211.

WetZel, R. G. 2001: Limnology. Lake and river ecosystems. Academic Press, San Diego. 